\title{
TEACHING ENGLISH VOCABULARY USING SONGS TO DEVELOPING STUDENTS' VOCABULARY MASTERY
}

\author{
Marni Bawawa \\ marnibawawa@unmus.ac.id \\ Program Studi Pendidikan Bahasa Inggris \\ Universitas Musamus
}

\begin{abstract}
The purpose of this research is to find out whether songs can develop students vocabulary mastery or not and to find out whether songs can increase of students' interest to develop the students' vocabulary mastery in second grade students at SMP Negeri 3Merauke or not. The subjects in this research were second grade students at SMP Negeri 3 Meraukeconsisting of 30 students. This research was classified into qualitative descriptive research. The researcher was used pretest and posttest design and conclude the data using two instrument; vocabulary test and then questionnaire. Vocabulary test to measure development in the English vocabulary mastery, the test is multiple-choice test. While the questionnaire to find out the students attitude toward the using songs in teaching English vocabulary. The questionnaire test consist of 5 questions. Based on the results of vocabulary tests on pretest and posttest, there was significant development. This can be seen on the percentage value of each test. The percentages of pretest was $40.66 \%$, while on the posttest increased namely $87.83 \%$. It means that using songs can develop students 'vocabulary mastery at grade VIII in SMP Negeri 3Merauke and the students' are more interest in learning English vocabulary by using songs than without using songs. It can be proved from the results of the questionnaire that most of the students' said that the using songs could help them to increase their interested in learning process.
\end{abstract} Kewords; songs, develop, vocabulary, mastery 


\section{INTRODUCTION}

English know as a international language used as tool communication in many countries, this is in line with Ramelan in Andriyani (2016:1), said that "English as an international language is used to communicate, to strengthen and to fasten relationship among all countries in the world in all fields, for example in tourism, business, science, technology". Because the importance of English, almost all countries use English, including Indonesia.

In Indonesia, English as the first foreign language which is taught in schools, starting from primary schools until university level using English language. It means that, English is very important role in modern life. Remembering the importance of English, it is necessary to learn English. Before we can speaking English, we must learn vocabulary, because if we are lack vocabulary we don't be able to speak English, because vocabulary is very important to learning English. This idea is supported by Hatch and Brown (1995:1), they say that "vocabulary is the basic or important part of building a language, plays a very basic role in terms of communication". It mean that, the more vocabulary we have the easier to speak English.

In learning English vocabulary, there are many media can help the teacher in teaching vocabulary for students and can develop students vocabulary, such as puppets, cartoon films, tape recorder, color passing, songs, games, and etc . In this research, the researcher chose a song as a media of learning vocabulary. Because the using English songs can develop the quality of students' vocabulary and can motivate students to get new words they have listened. In addition, most learners enjoy singing songs, and songs can often be a variety from the routine of learning the foreign language. According to Zatnikasari in Pradana (2014:31), Songs are also effective to make the students to remember the words easily and feel more motivated in the class because they learn in an interesting way. it's mean that, One of the ways in creating an enjoyable learning atmosphere is by using songs as teaching media in the classroom to develop students vocabulary mastery. 
By using songs in teaching English vocabulary, students will feel a pleasant atmosphere, students can easily remember vocabulary because it is already familiar to their ears and their can learn and understand new vocabulary which comes from songs. According to Dale in Gasma (2017:4), states that songs are good at introducing vocabulary because songs provides a meaningful context for the vocabulary. It supported by Cebula in Gasma (2017:4), who said that the students who participate in learning through songs usually express themselves easily and pick up a lot of new words. Listening to music also can provide enjoyment and stimulate cultural interest. It means when students listen to their favorite English songs, they are motivated personally to find out what songs are about, understanding the meaning of a word, and they can get more vocabularies from songs lyrics they heard. Thus, students' desire to listening to English songs are expected to improve the students' vocabulary mastery.

From the result of observation at SMP Negeri 3Merauke, the researcher found the problem that many of the students get the problems with vocabulary. Most of the students still have difficulties in vocabulary when learning English, and the understanding of students toward the materials are less, they are not interested in learning English, and they felling boring when learn English. Therefore, researcher interest to teaching English using songs to develop students' vocabulary mastery in second grade students at SMP Negeri 3 Merauke. The songs to teach is English songs. The researcher hope by using song in teaching English vocabulary can develop students' vocabulary mastery and the students are more interested in learning English.

The purpose of this study is to find Whether songs can develop students' vocabulary mastery at Grade VIII in SMP Negeri 3 Merauke or not and whether use songs can increase the students' interest to develop the students' vocabulary mastery at Grade VIII in SMP Negeri 3 Merauke or not. 


\section{METHOD}

This research the categorized as qualitative research. The research was used pretest and posttest design to measure students' achievement in learning English vocabulary mastery. The population and sample in this research are second grade students in SMP Negeri 3 Merauke the academic year 2019/2020 the located school in KampungKuper. The number of students consists of 30 students. The purposes in this test to find out the achievement students in learning English vocabulary and types of test consist vocabulary test and questionnaire.

The technique of data collection consist of pretest, treatment and posttest and questionnaire. The first of Pretest, The researcher given test in order can see the students' achievement in learning vocabulary before using songs. The second of treatment, the researcher given a treatment through songs to students, to developing the students' vocabulary mastery. The researcher applied the English songs in teaching learning proses. The third of posttest is to see whether students get progress in learning English vocabulary using songs or not. The last of questionnaire, after giving post-test to students, researcher give the questionnaire about students' interest toward the used of songs in teaching English vocabulary. Technique of data analysis, the researcher was classify the data based on the results of the research obtained. The researcher arranged the description of the data from pre-test, post-test and questionnaire. The researcher described and discussed the finding of the research in the form of systematic classification. The researcher was analyze the results of the pre-test and post-test using the proposed formula by Octaviany (2007:39). The formula is follow:

The percentage $=\frac{\text { The number of right answer }}{\text { The number of item }} \times 100 \%$

While the average of the students' result was counted by using formulated the following:

The average of the students' test result $=\frac{\text { The total of the percentage }}{\text { The number of the students }}$ 


\section{FINDINGS AND DISCUSSION}

In this section, the researcher want to discuss the data has been collected. The researcher got the data of the research which had been conducted on students at grade VIII in SMP Negeri 3 Merauke. There were 30 students followed this test. Analysis the data starting from pretest, treatment, posttest and questionnaire.

\section{Students' Vocabulary}

\section{a. Pretest}

The aim of this test was to know the scoring students in vocabulary mastery before make treatment. The pre-test was conducted on 30 students and they had to answer 20 multiple choice test. The result of students' vocabulary before using songs can be seen as table below.

Table 1. Result of Pretest

\begin{tabular}{|c|l|c|c|}
\hline No & Students' Name & Total Score & \% \\
\hline 1 & A. M. W & 6 & 30 \\
\hline 2 & A. D. M & 11 & 55 \\
\hline 3 & A. A & 7 & 35 \\
\hline 4 & A. S & 8 & 40 \\
\hline 5 & B. B. T & 11 & 55 \\
\hline 6 & B. A. A. L & 7 & 35 \\
\hline 7 & D. B & 5 & 25 \\
\hline 8 & D. F & 8 & 40 \\
\hline 9 & F. W. K & 7 & 40 \\
\hline 10 & F. O. M & 7 & 35 \\
\hline 11 & G & 5 & 25 \\
\hline 12 & G. M. B & 7 & 35 \\
\hline 13 & I. P. A & & \\
\hline
\end{tabular}




\begin{tabular}{|c|l|c|c|}
\hline 14 & I. R. B. T & 8 & 40 \\
\hline 15 & I. W & 10 & 50 \\
\hline 16 & J. E. K & 11 & 55 \\
\hline 17 & L. H & 9 & 45 \\
\hline 18 & M. A. A & 5 & 25 \\
\hline 19 & M. C. T & 8 & 40 \\
\hline 20 & M. S. M & 5 & 25 \\
\hline 21 & N. A. T & 9 & 45 \\
\hline 22 & P. P & 6 & 30 \\
\hline 23 & R. R. M & 13 & 65 \\
\hline 24 & R. C. P & 11 & 55 \\
\hline 25 & R. P. L & 8 & 40 \\
\hline 26 & R. D. B. K & 9 & 45 \\
\hline 27 & S. T. H & 7 & 35 \\
\hline 28 & S. C. T & 13 & 65 \\
\hline 29 & Y. R & 7 & 35 \\
\hline 30 & Y. A. N & 40 \\
\hline & Total of the students $=\mathbf{3 0}$ & $\mathbf{1 2 2 0}$ \\
\hline & \multicolumn{2}{|l|}{ Mean } & $\mathbf{4 0 . 6 6}$ \\
\hline
\end{tabular}

Based on the results above, showing mean score of students pre-test above is $40.66 \%$. The result is very low from the criteria which set by the Department of Education and Culture. According to criteria Depdikbud (1994: 34), learning process can be said to be successful if students' achievement is $65 \%$. From this result, the researcher concluded that the students' vocabulary mastery was still low. This condition means that, students need to develop their vocabulary mastery. To develop students' vocabulary mastery, researcher need to give treatment for students with the using songs. 


\section{b. Treatment}

The researcher used two songs in this treatment. The treatment is given to students during 4 meetings with using songs, the songs given are songs based to the level of students. According Burhayani (2013: 69), stated that students are very happy to listen to songs because the songs has a very large tendency to attract attention. It means that the use of songs in teaching vocabulary is one of the alternative media to help the students' to construct and develop their vocabulary mastery. Lozanov in Widhiastuti (2017: 21), states that the atmosphere created by songs enhances the ability to remember new vocabularies. it is because people found it much easier to memorize something that is fun and melodic than normal sentence. Based on the explanation above, the researcher concludes that songs have potential to develop students' vocabulary mastery.

\section{c. Posttest}

Based on the results of treatment, most of students' were very enthusiastic for followed the learning process. Almost of the students' enjoy the learning process, they more active and then they can followed all of activities during the learning process. After treatment has finished, given of posttest to see the result of the students'. It can see in the table bellow

Table 2. Result of Posttest

\begin{tabular}{|c|l|c|c|}
\hline No & Students' Name & Total Score & \% \\
\hline 1 & A. M. W & 17 & 85 \\
\hline 2 & A. D. M & 20 & 100 \\
\hline 3 & A. A & 17 & 85 \\
\hline 4 & A. S & 20 & 100 \\
\hline 5 & B. B. T & 18 & 90 \\
\hline 6 & B. A. A. L & 13 & 65 \\
\hline 7 & D. B & 15 & 75 \\
\hline
\end{tabular}




\begin{tabular}{|c|l|c|c|}
\hline 8 & D. F & 18 & 90 \\
\hline 9 & F. W. K & 15 & 75 \\
\hline 10 & F. O. M & 18 & 90 \\
\hline 11 & G & 20 & 100 \\
\hline 12 & G. M. B & 16 & 80 \\
\hline 13 & I. P. A & 20 & 100 \\
\hline 14 & I. R. B. T & 16 & 80 \\
\hline 15 & I. W & 20 & 100 \\
\hline 16 & J. E. K & 19 & 95 \\
\hline 17 & L. H & 20 & 100 \\
\hline 18 & M. A. A & 14 & 70 \\
\hline 19 & M. C. T & 18 & 90 \\
\hline 20 & M. S. M & 13 & 65 \\
\hline 21 & N. A. T & 13 & 65 \\
\hline 22 & P. P & 15 & 75 \\
\hline 23 & R. R. M & 20 & 100 \\
\hline 24 & R. C. P & 20 & 100 \\
\hline 25 & R. P. L & 18 & 90 \\
\hline 26 & R. D. B. K & 19 & 95 \\
\hline 27 & S. T. H & 20 & 100 \\
\hline 28 & S. C. T & 18 & 90 \\
\hline 29 & Y. R & 20 & 100 \\
\hline 30 & Y. A. N & 17 & 85 \\
\hline & Total of the students & $\mathbf{3 0}$ & $\mathbf{2 6 3 5}$ \\
\hline & & & $\mathbf{8 7 . 8 3}$ \\
\hline & & & \\
\hline
\end{tabular}

The result of post-test above proved that songs can develop the students' vocabulary mastery. This can be seen from the mean score students of posttest is $87,83 \%$, and the result is higher than the result of pre-test. It means that song 
can be one very useful media in teaching English vocabulary because with the using song can make students more easily understand and remembering learning material, and increase students' vocabulary mastery. it is line with Whrenshall in Burhayani (2013: 69), state that " there has been plenty of evidence that memorizing rhythms and lyrics from songs helps to increase vocabulary". Lozanov in Widhiastuti (2017: 21), he also states that the atmosphere created by songs enhances the ability to remember new vocabularies. It is because people found it much easier to memorize something that is fun and melodic than normal sentence. Therefore, by using songs in learning English vocabulary can develop students' vocabulary mastery in SMP Negeri 3 Merauke, especially at grade VIII.

\section{Interest}

To find out the students attitude toward the using songs in learning vocabulary, the researcher used a questionnaire. The researcher gave 5 items to be answered and students answer "yes or no" the result are as follow:

Table 3. The result of Questionnaire

\begin{tabular}{|c|c|l|l|}
\hline No. & $\begin{array}{c}\text { Item } \\
\text { number }\end{array}$ & \multicolumn{1}{|c|}{ "Yes" answer } & "No" answer \\
\hline 1. & 1 & $24(80 \%)$ & $6(20 \%)$ \\
\hline 2. & 2 & $30(100 \%)$ & $0(0 \%)$ \\
\hline 3. & 3 & $28(93.33 \%)$ & $2(6.67 \%)$ \\
\hline 4. & 4 & $20(66.67 \%)$ & $10(33.33 \%)$ \\
\hline 5. & 5 & $26(86.67 \%)$ & $4(13.33 \%)$ \\
\hline
\end{tabular}

From of the result of the questionnaire above, it can be explained as a follow:

Question number 1. Whether the students were interested to learn using songs given or not. There are $24(80 \%)$ students answering "yes" and there are 6 $(20 \%)$ students answering "no". From the answered question number 1, it can 
see that the students interested in learning English vocabulary using songs. Supported the result of this research, Philips (2003: 68), state that songs can be used as a tool to increase students' interest or motivation in learning. Students' really enjoy learning by using songs.

Questionnumber 2. Whether the songs given help the students in learning vocabulary or not. All the students answered "yes" (30/100\%). Its mean that, using song in teaching English vocabulary make students interested. This result is supported bySiskova (2008:15), stated that songs can be used to understand and produce language, remember words over time and be able to recall them readily, including developing strategies to overcome gaps in word knowledge, and can also overcome the use of unknown words. In means that using songs in learning English vocabulary can help the students in vocabulary mastery and can increase of interested students in learning English.

Question number 3. Whether learn with media songs can add to your enthusiasm in learning English. There are 28 (93.33\%) students answering "yes" and there are $2(6.67 \%)$ students answering "no". From the answer question number 3 , it can see that almost students benefit from the songs. Burhayani (2013: 69), stated that "students are very happy to listen to songs because the songs has a very large tendency to attract attention. This shows that students are very enthusiastic in learning using songs, this can be seen from the results of the vocabulary test, because there are differences in vocabulary mastery before and after the song is given.

Question number 4. Whether types of vocabularies learn often students used in their daily lives or not. There were 20 (66.67\%) students answering "yes" and there are $10(33.33 \%)$ students answering "no". it is mean that, the relationship between vocabulary and learned topics learned in treatment is the vocabulary that students often use in their daily lives.

Question number 5. Whether yes or not the media that had been conducted should be given continuously. There are 26 (86.67\%) students answering "yes" and there are $4(13.33 \%)$ students answering "no". Its mean that, almost all 
students' expected the songs that have been given can be studied continuously. It is line with Slameto (2003: 58) state that students who are interested in learning having a fixed tendency to remember to pay attention and learn something continuously. It means that students' are interested in learning English using songs.

\section{CONCLUSION}

Based on the research finding, the researcher concludes that:

The used of song in teaching English vocabulary is more effective to developing the students' vocabulary mastery in second grade students at SMP Negeri 3 Merauke. It is supported by the result score of the pre-test and posttest students showed which is value of pretest is lower of posttest $(40.66<87.83)$.

The used of songs in teaching English vocabulary has given to students interest in learning English in second grade students at SMP Negeri 3Merauke in the academic year 2019/2020, it is supported by result ofstudents questionnaire, where the students said that use of songs could help them to increase their interest in learning process, and through songs also makes them to memorize vocabulary easily

\section{Reference}


Andriyani, S. (2016). The Implementation of English Immersion Program for Facing Globalization Era. Jepara: Islamic University of NahdlatulUlama.

Burhayani. (2013). The effectiveness of Teaching Vocabulary through Songs to the Second Years Students' of IkatanKesejahteraanTentara (IKKT) Elementry School West Jakarta. Bangkok: AUA Language Center.

Gasma, Y. 2017. The Implementation of English Song In Teaching Vocabulary at The First Grade Of Senior High School. Lampung: Universitas of Lampung. Hatch, E. \& Brown, C. (1995).Vocabulary, Semantics, and Language Education. Cambridge: Cambridge University Press.

Hatch, E. \& Brown, C. (1995).Vocabulary, Semantics, and Language Education. Cambridge: Cambridge University Press.

Octaviany, Y. (2007). The Application of Total Physical Response in Teaching English Vocabulary to The Fourth Graders Of SD Negeri 04 KrajankulonKaliwungu Kendal In The Academic Year of 2006/2007. Semarang: Semarang State University.

Phillips, Sara. (2003). Young learners. Oxfor: Oxford Universiry Press.

Pradana R., Khotimah A. N., Premesti P. W. and Wangi W. 2014. A Descriptive Study of Using English Songs In Teaching Listening To Develop Students' Vocabulary Mastery At The Tenth Grade Students Of Ipa 1 Of Man SronoBanyuwangi. Banyuwangi: Universitas PGRI Banyuwangi. 30-37.

Siskova, Dagmar. (2008). Teaching Vocabulary Through Music. Brno: Masaryk University. Published Paper.

Slameto. (2003). BelajardanFaktor- Faktor yang Mempengaruhinya. Jakarta: RinekaCipta.

Widhiastuti, W. Dwi. (2012). The Effect of English Pop Songs in BuildingVocabulary to Seventh Grade Students of SMP AngkasaAdisutjiptoYogyakarta in The Academic Year Of 2010/2011. Yogyakarta: YogyakartaState University. 